DOI: $10.1515 /$ pts-2017-0012

APPLIED PHYSICS

\title{
RESEARCH OF SURFACE ROUGHNESS ANISOTROPY
}

\author{
N.Bulaha, J.Rudzitis, J.Lungevics, O.Linins, J.Krizbergs \\ Institute of Mechanical Engineering, \\ Riga Technical University, \\ 6 Ezermalas Str., LV-1006, Riga, LATVIA \\ e-mail:mti@rtu.lv
}

\begin{abstract}
The authors of the paper have investigated surfaces with irregular roughness for the purpose of determination of roughness spacing parameters perpendicularly to machining traces $-R S m_{1}$ and parallel to them $-R S m_{2}$, as well as checking the relationship between the surface anisotropy coefficient $\mathrm{c}$ and surface aspect ratio Str from the standard LVS EN ISO 25178-2. Surface roughness measurement experiments with 11 surfaces show that measuring equipment values of mean spacing of profile irregularities in the longitudinal direction are not reliable due to the divergence of surface mean plane and roughness profile mean line. After the additional calculations it was stated that parameter Str can be used for determination of parameter $R \mathrm{Sm}_{2}$ and roughness anisotropy evaluation for grinded, polished, friction surfaces and other surfaces with similar characteristics.
\end{abstract}

Keywords: anisotropy coefficient, roughness spacing parameters, surface texture, texture aspect ratio.

\section{INTRODUCTION}

Analysis of surface roughness spacing parameters [1] provides that for surfaces with irregular roughness spacing parameters values occasionally are not reliable due to the fact that mean plane of surface roughness and the roughness profile mean line are located at different levels, in particular, it is expressed for mean spacing of profile irregularities in the longitudinal direction. Thereby difficulties with surface anisotropy evaluation are arising.

In order to solve the existing problems, scientists offer using the visual method, which will allow identifying more reliable values of spacing parameters $R S m_{1}$ and $R \mathrm{Sm}_{2}$. In addition, it is reasoned that the surface roughness anisotropy can be described by the surface aspect ratio Str from standard EN ISO 25178-2: 2012 [2], which is essentially equal to the roughness anisotropy coefficient $c$.

$S t r=c$.

By contrast, variants of surface roughness anisotropy evaluation offered in [1] 
are justified only in theory, which is why it is important to prove them with practical experiments.

\section{EXPERIMENTAL PART}

To test relation (1) according to which, with specially oriented surface roughness correlation function $\rho\left(\tau_{1}, \tau_{2}\right)[3]$, texture aspect ratio Str is equal to surface roughness anisotropy coefficient $\mathrm{c}$, the authors of the paper have studied 11 surfaces obtained by different technological methods (see Table 1 and Table 2).

Surface roughness measurement experiment was carried out on the profilograph-profilometer Taylor Hobson Talysurf Intra 50. It is the measuring equipment that provides determination of surface roughness parameters in the 3-D coordinate system. Before the start of the experiment, the 2-D surface roughness measurements were made in order to determine the sample and evaluation length for each sample surface. In addition, a required number of points - 300 points - were chosen, considering the developed methodology mentioned in [4]. After the roughness measurement experiment, the filtering of obtained surface topography was carried out to make surface leveling and separate from it form and waviness occurring at various mechanical machining conditions (part clamping, deflection, thermal processes, vibrations and the cutting-tool path deviation). After surface filtration, the 3D roughness parameters and additional profile parameters, which were extracted from different surface cross sections, were determined. The values provided in Table 1 and Table 2 are mean values obtained from three measurements of surfaces.

Table 1 contains images of each 3D surface roughness $h(x, y)$ and 3D surface roughness autocorrelation function $\rho\left(\tau_{1}, \tau_{2}\right)$ in order to show the characteristics of the technological process. Parameter $S a$ is provided as well, but in crosswise direction 1 (crosswise to machining (friction) traces) and in longitudinal direction 2 - parameters $R a_{1}, R a_{2}$.

Table 1

Comparison between 3D and 2D Height Parameters of Irregular Surface Roughness

\begin{tabular}{|c|c|c|c|c|}
\hline Machining & Topography, correlation function & $S a, \mu \mathrm{m}$ & $R a 1, \mu \mathrm{m}$ & $R a 2, \mu \mathrm{m}$ \\
\hline $\begin{array}{l}1 . \\
\text { Surface grinding } \\
\text { (Rugotest No. } \\
104, \\
\text { surface No.3) }\end{array}$ & $\rho\left(\tau_{1}, \tau_{2}\right)$ & 0.048 & 0.036 & 0.008 \\
\hline
\end{tabular}




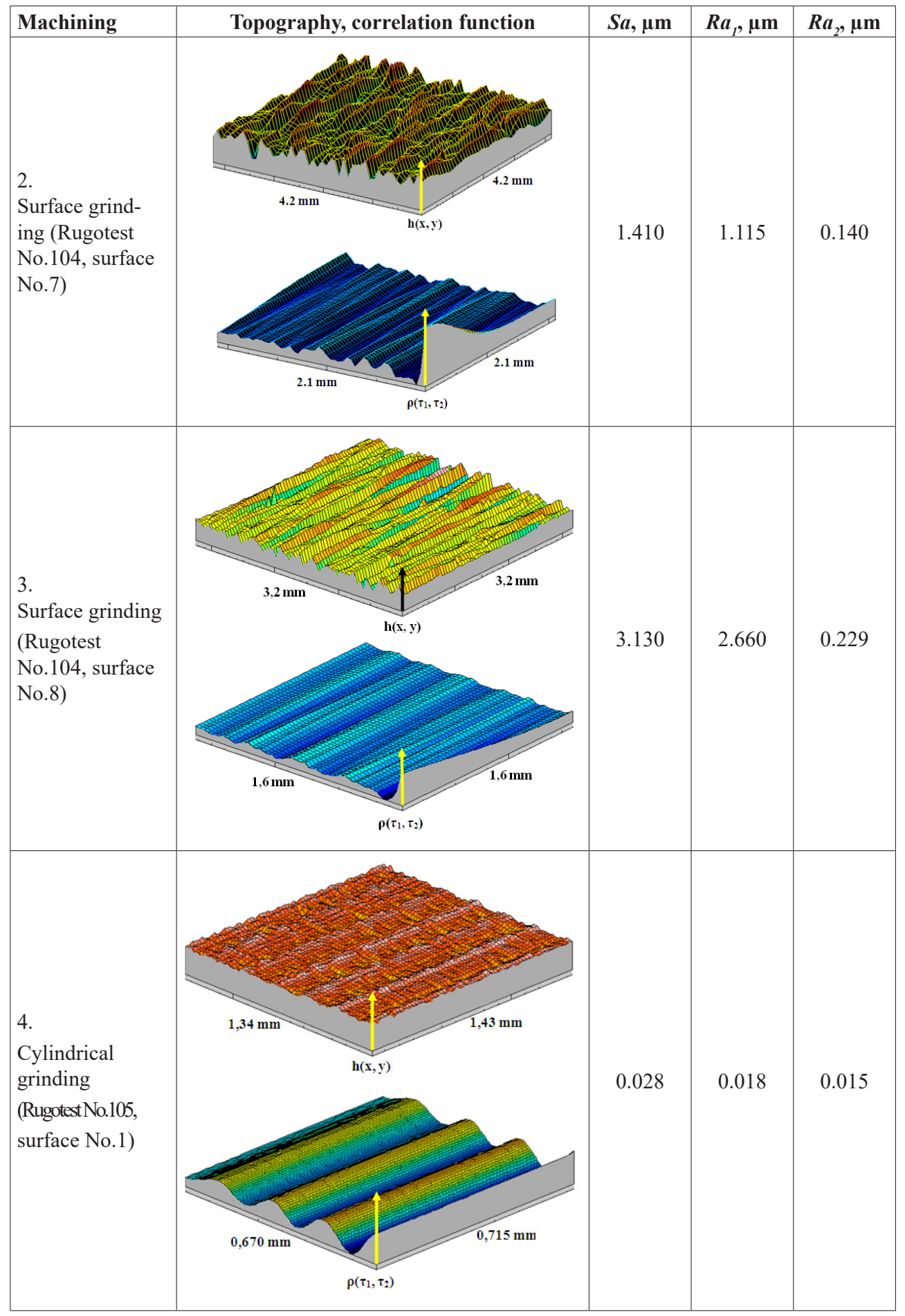




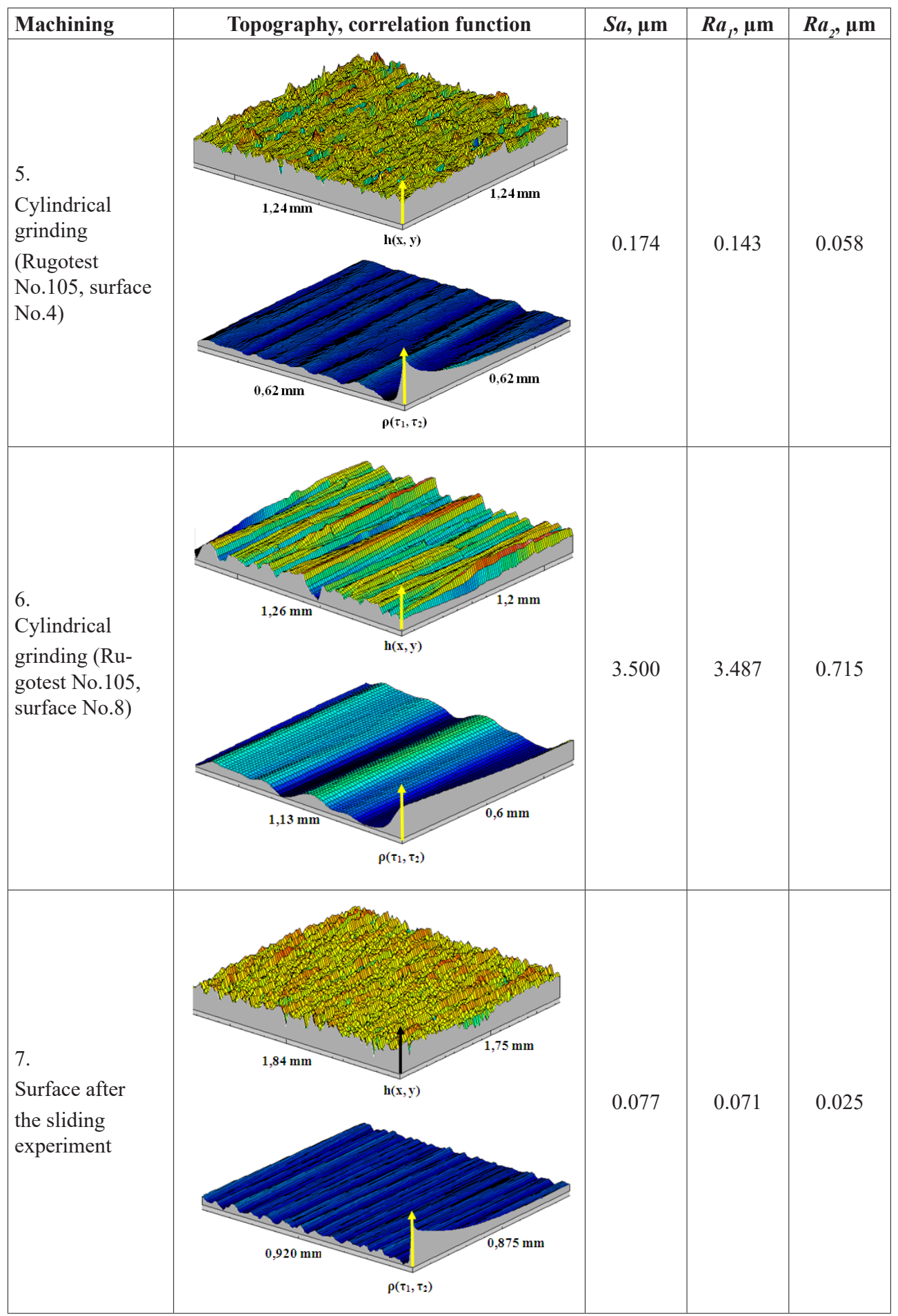




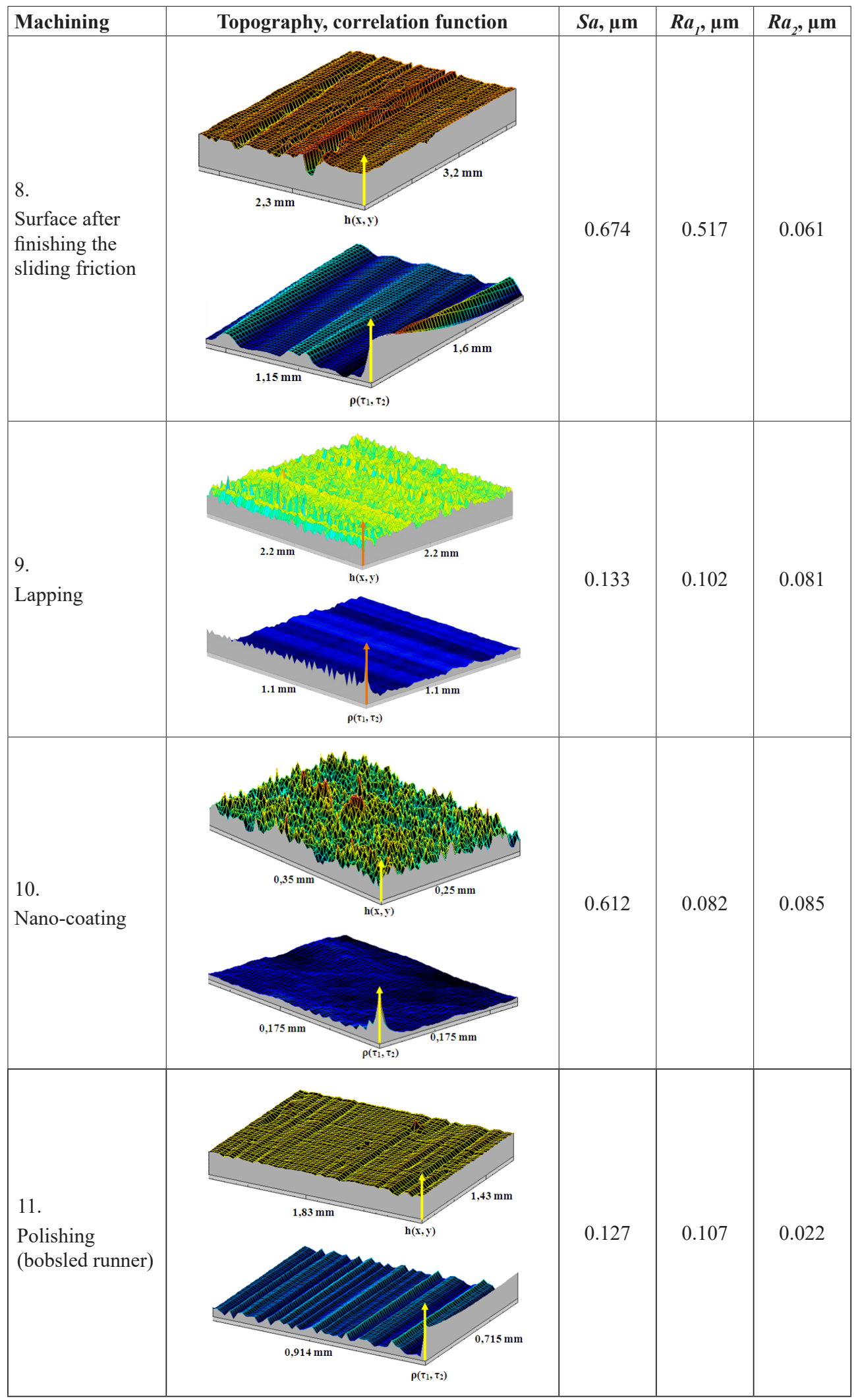


Table 2 comprises mean spacing of profile elements $R S m_{1}$ and $R S m_{2}$, and surface anisotropy characteristics Str and $c$. Furthermore, mean spacing of profile irregularities $R S m_{2}$ was acquired using 2 methods: using measuring equipment Taylor Hobson Intra $50\left(\mathrm{RSm}_{2}\right.$ - mean spacing of profile irregularities in longitudinal direction measured with the measuring equipment) and using visual determination method $\left(\left[\mathrm{RSm}_{2}\right]_{v i z}\right.$ - mean spacing of profile irregularities in longitudinal direction determined by visual inspection). It should be noted that based on evaluation given by 5 specialists the visual method allows one to determine $R S m$ values with a $10 \%$ margin of error. The error is not small; however, it produces better results than using an incorrect value of mean spacing of profile irregularities.

Table 2

Analysis of irregular surface roughness spacing parameters

\begin{tabular}{|c|c|c|c|c|c|c|}
\hline No. & Machining & $\begin{array}{c}R S m_{1} \\
\mathrm{~mm}\end{array}$ & $\begin{array}{c}\boldsymbol{R S m _ { 2 }} \\
\mathrm{mm}\end{array}$ & $\begin{array}{l}{\left[\boldsymbol{R S m _ { 2 }}\right]_{v i z}} \\
\mathrm{~mm}\end{array}$ & Str & $c$ \\
\hline 1. & $\begin{array}{c}\text { Surface grinding (Rugotest 104, } \\
\text { surface No.3) }\end{array}$ & 0.088 & 0.131 & 0.400 & 0.144 & 0.150 \\
\hline 2. & $\begin{array}{c}\text { Surface grinding (Rugotest 104, } \\
\text { surface No.7) }\end{array}$ & 0.140 & 0.348 & 4.200 & 0.031 & 0.033 \\
\hline 3. & $\begin{array}{c}\text { Surface grinding } \\
\text { (Rugotest No.104, surface } \\
\text { No.8) }\end{array}$ & 0.095 & 0.087 & 3.200 & 0.024 & 0.029 \\
\hline 4. & $\begin{array}{c}\text { Cylindrical grinding } \\
\text { (Rugotest No.105, surface } \\
\text { No.1) }\end{array}$ & 0.073 & 0.051 & 1.430 & 0.055 & 0.051 \\
\hline 5. & $\begin{array}{c}\text { Cylindrical grinding } \\
\text { (Rugotest No.105, surface } \\
\text { No.4) }\end{array}$ & 0.059 & 0.101 & 1.250 & 0.047 & 0.047 \\
\hline 6. & $\begin{array}{l}\text { Cylindrical grinding (Rugotest } \\
\text { No.105, surface No.8) }\end{array}$ & 0.080 & 0.141 & 1.200 & 0.063 & 0.066 \\
\hline 7. & $\begin{array}{c}\text { Surface after the sliding } \\
\text { experiment }\end{array}$ & 0.029 & 0.031 & 1.750 & 0.013 & 0.016 \\
\hline 8. & Finishing & 0.100 & 0.160 & 3.200 & 0.029 & 0.031 \\
\hline 9. & Lapping & 0.049 & 0.044 & 0.157 & 0.333 & 0.312 \\
\hline 10. & Nano-coating & $0.016^{*}$ & 0.011 & 0.025 & 0.612 & 0.640 \\
\hline 11. & Polishing (bobsled runner) & 0.030 & 0.032 & 1.430 & 0.018 & 0.021 \\
\hline
\end{tabular}

*Determined by visual inspection

In Table 1, values of profile parameters $R a_{1}$ and $R a_{2}$ were compared with $S a$ values for each machining type. If these parameters are close in their numerical value (more precisely - have the same order of magnitude), it means that the mean lines of the corresponding profiles are positioned close to the mean plane of roughness, spacing parameters of these profiles can be considered probable for the mean plane level and, therefore, they characterise 3D roughness surface. If that is not the case, $R S m_{1}$ and $R s m_{2}$ values are determined visually.

In crosswise direction, there is only one surface (nano-coated) with values of parameter $R a_{1}$ significantly different from value of parameter $S a$. In this case, 
parameter $R S m_{1}$ cannot be considered as belonging to the level of the mean plane and cannot be used for calculation of anisotropy coefficient c. $R S m_{l}$ value of this surface was determined visually.

As for the other surfaces, $R S m_{l}$ values obtained with the measuring equipment were eligible for usage in calculating $\mathrm{c}$ according to formula (1).

Parameter $R \mathrm{Sm}_{2}$ used in formula (1) is determined in a similar manner. If $R a_{2} \approx S a$, parameter $R S m_{2}$ obtained with the measuring equipment can be used to calculate anisotropy coefficient c, if $R a_{2} \ll S a$, this means spacing of profile irregularities is determined visually and is written as $\left[\mathrm{RSm}_{2}\right]_{v i z}$. As shown in Table 2, all 11 surfaces required $\left[\mathrm{RSm}_{2}\right]_{v i z}$ value to be determined.

When the values of mean spacing of profile elements are obtained, anisotropy coefficient $\mathrm{c}$ is calculated according to formula [1]:

$$
c=\frac{R S m_{1}}{R S m_{2}} .
$$

The calculated $c$ values are compared to values of 3D surface texture aspect ratio Str (see Fig. 1).

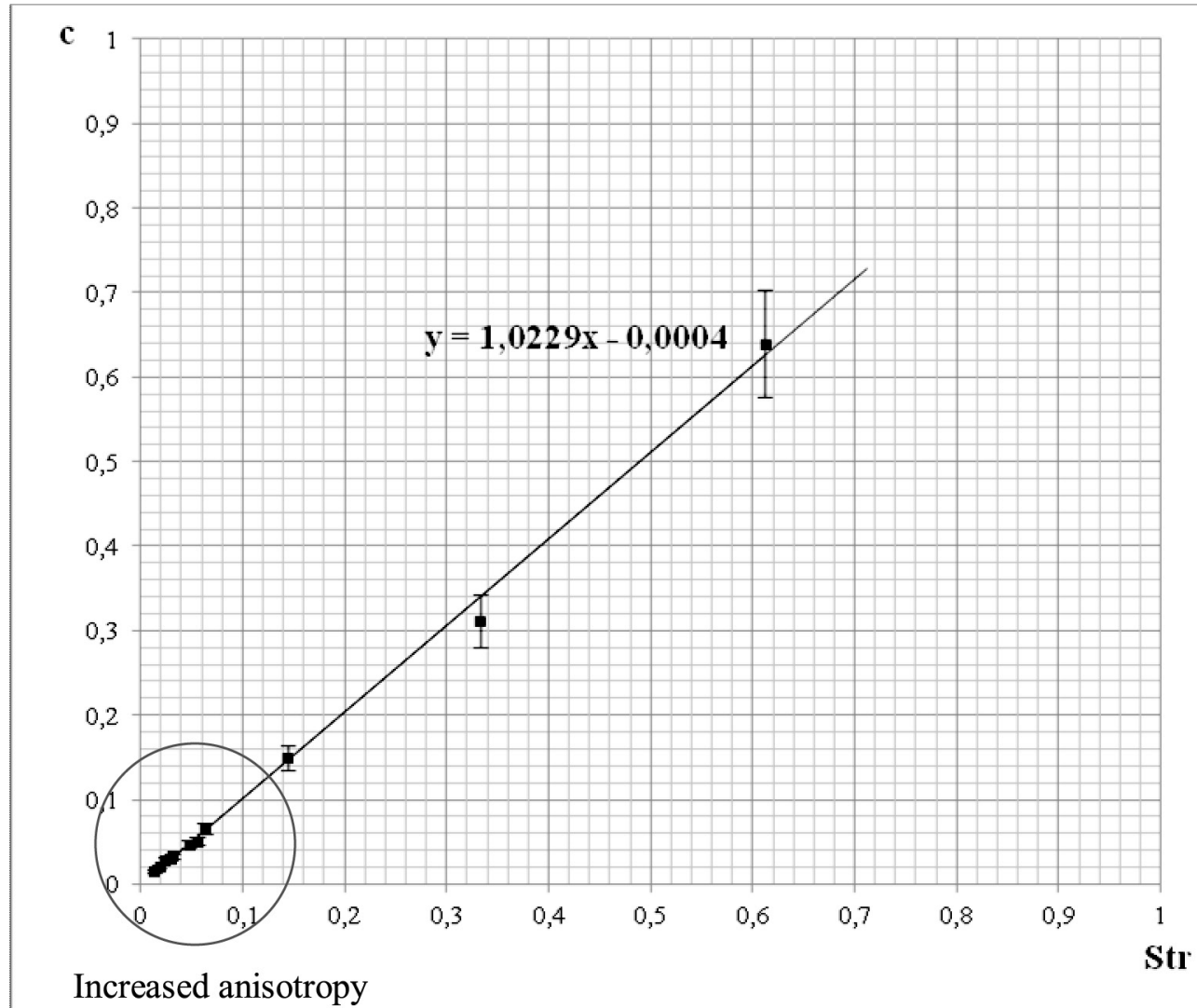




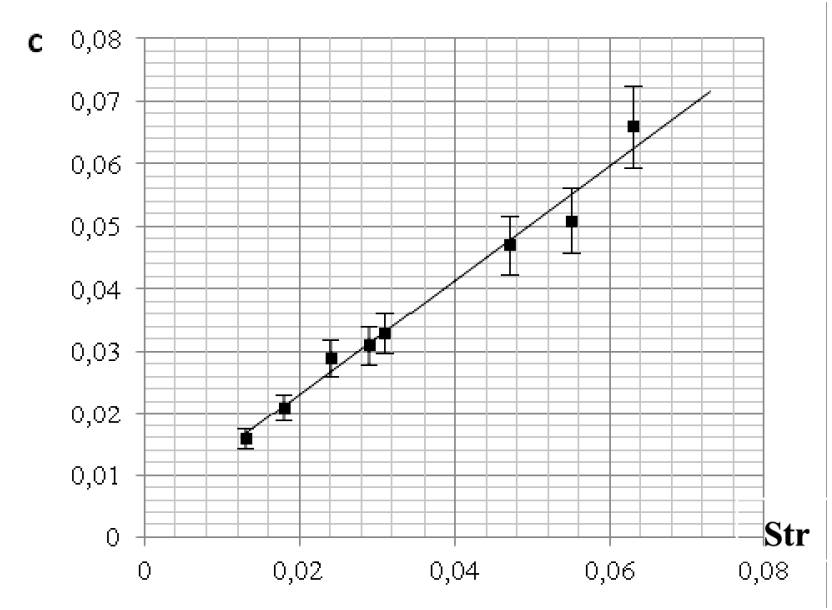

$\mathrm{b}$

Fig. 1. Relationship between parameters $c$ and Str (with $\Phi$ marked visual detection error range of parameter $c$ ): $\mathrm{a}$ - the whole surface, $\mathrm{b}$ - surfaces with increased anisotropy.

Data provided in Fig. 1 reflect formula (1) reasonably accurately. It is clearly seen in surfaces with anisotropy coefficient $c<0.1$ (surfaces with increased anisotropy). Autocorrelation function of these surfaces is notably oriented along crosswise and longitudinal profiles.

\section{EVALUATION METHODOLOGY FOR ANISOTROPY}

Surface roughness anisotropy can be evaluated following the steps listed below:

1. Create 3D surface roughness topography.

2. Determine surface texture parameters $S a$ and $S t r$.

3. Chose surface sections that are perpendicular and parallel to the traces of surface machining.

4. Determine height parameters $R a_{1}$ and $R a_{2}$ for surface roughness profiles and spacing parameters $R S m_{1}$ and $R S m_{2}$.

5. Compare mean values of $R a_{1}$ and $R a_{2}$ of the profiles with surface texture parameter $S a$.

5.1. If values of both parameters are close to or almost the same as $S a$ values, it can be considered that the mean lines of all profiles are located at the mean plane level and, thus, it can be assumed that $R S m_{l}$ and $R \mathrm{Sm}_{2}$ values characterise the surface.

5.2. If parameter $R a_{1}$ is close to $S a$ in value while parameter $R a_{2}$ significantly differs, mean spacing of profile elements $R S m_{2}$ is determined using surface texture aspect ratio by formula: $R S m_{2}=R S m_{1} / S t r$.

5.3. If neither of the parameters $\left(R a_{1}\right.$ and $\left.R a_{2}\right)$ is close to $S a$ value, anisotropy is evaluated using the visual method and formula (1): $c=R S m_{l} /$ $\mathrm{Rsm}_{2}$. 


\title{
4. CONCLUSIONS
}

Within the present research, the analysis of roughness anisotropy for 11 surfaces with irregular character has been made. Firstly, anisotropy coefficient $c$ has been calculated by measuring mean spacing of profile irregularities for surface roughness using measuring equipment Taylor Hobson Talysurf Intra 50 and, in addition, using the visual method, when a mean line of a profile and mean plane of a surface are at different levels. Then the calculated values of anisotropy coefficient $c$ have been compared to the values of surface texture aspect ratio Str. During the research, it has been established that surface texture parameter Str can be applied to surface roughness anisotropy analysis and calculations of mean spacing of profile irregularities. In the research, the methodology for surface roughness anisotropy determination has been proposed.

\section{REFERENCES}

1. Rudzitis, J., Bulaha, N., Lungevics, J., Linins, O., \& Berzins, K. (2017). Theoretical analysis of spacing parameters of anisotropic 3D surface roughness. Latvian Journal of Physics and Technical Sciences, 54(2), pp., 55-63.

2. International Organization for Standardization. (2012). Geometrical product specifications (GPS) - Surface texture: Areal - Part 2: Terms, definitions and surface texture parameters. ISO 25178-2:2012.

3. Rudzitis, J. (2007). Mechanics of Surface Contact. Part 1. Parameters of Surface Roughness Profile. Riga: Riga Technical University (in Russian).

4. Bulaha, N., Rudzitis, J., Lungevics, J., \& Cudinovs, V. (2016). Measurement principles of 3D roughness parameters. In 15th International Conference "Engineering for Rural Development”, 25-27 May 2016 (pp.1059-1064). Latvia, Jelgava: Latvia University of Agriculture, Latvia.

\section{VIRSMAS RAUPJUMA ANIZOTROPIJAS IZPĒTE}

\author{
J.Rudzitis, N.Bulaha, J.Lungevičs, O.Liniņš, J. Krizbergs
}

Kopsavilkums

Dotajā rakstā tika veikti virsmu ar neregulāru raupjumu pētîjumi, ar mērkịi noteikt raupjuma soḷa parametrus perpendikulāri apstrādes pēdām $R S m_{1}$ un paralēli tām $-R S m_{2}$, kā arī pārbaudīt sakarību starp virsmas anizotropijas koeficientu $c$ un virsmas tekstūras indeksu Str no LVS EN ISO 25178-2. Virsmas raupjuma mērīšanas eksperimenti ar 11 virsmām rāda, ka mēraparāta soḷa vērtības virsmas garenvirzienā nav ticamas, sakarā ar virsmas vidējās plaknes un profila viduslīnijas nesakrišanu. Veicot papildus aprēķinus tika secināts, ka parametru Str var pielietot raupjuma anizotropijas novērtēšanai, piemēram, slīpētām, pulētām, berzes virsmām un citām virsmām ar līdzīgām īpašībām.

12.12.2016. 